\title{
Primary leiomyosarcoma of the nipple-areola complex: Report of a case and review of literature
}

\author{
Lai-ching WONG ${ }^{1}$, Po-chi HUANG ${ }^{1}$, Shi-ping LUH ${ }^{\dagger 2}$, Chiun-sheng HUANG ${ }^{3}$ \\ $\left({ }^{1}\right.$ Department of Pathology, Taichung Hospital, Executive Yuan Department of Health, Taichung 401, Taiwan, China) \\ $\left({ }^{2}\right.$ Department of Surgery, Chung-Shan Medical University and Hospital, Taichung 402, Taiwan, China) \\ ( ${ }^{3}$ Department of Surgery, National Taiwan University Hospital, Taipei 100, Taiwan, China) \\ †E-mail: luh572001@yahoo.com.tw \\ Received Nov. 7, 2007; revision accepted Jan. 7, 2008
}

\begin{abstract}
Primary leiomyosarcoma of the nipple-areola complex is extremely rare. Less than ten such cases have been reported in English literature so far. Herein we describe a 52-year-old female presenting with a $1.5 \mathrm{~cm} \times 1.1 \mathrm{~cm} \times 0.7 \mathrm{~cm}$ nodular lesion over her left nipple, and leiomyosarcoma was proved by pathological examination of the excised specimen. Positron emitted tomogram (PET) revealed no abnormal signal other than the primary site. Microscopically, this poorly circumscribed tumor was composed of interlacing bundles of smooth muscle cells with bizarre and pleomorphic nuclei, as well as prominent nucleoli. Its mitotic count was up to 7 mitoses per 10 high power fields (HPF). Immunohistochemical study of tumor cells revealed positive stain for $\alpha$-smooth muscle actin and vimentin; and negative for cytokeratin, CD34 and S-100. Left simple mastectomy was undertaken and no residual mass lesion was noted on the resected specimen. Related literatures about the diagnosis and treatment for breast leiomyosarcoma will be presented here.
\end{abstract}

Key words: Breast, Leiomyosarcoma, Mastectomy doi: $10.1631 /$ jzus.B0720246

Document code: A
CLC number: R737

\section{INTRODUCTION}

Sarcomas of the breast account for less than $0.1 \%$ of all malignant tumors of the breast. Leiomyosarcomas belong to a less common subgroup $(5 \%$ to $10 \%)$ of sarcomas of the breast (Adem et al., 2004; Hussien et al., 2001; Munitiz et al., 2004). There were only 27 cases being reported in English literature (Abd El All, 2006; Gupta, 2007; Jayaram et al., 2005; Munitiz et al., 2004; Vu et al., 2006). Leiomyosarcoma of the nipple-areola complex is even rarer. Herein a patient whose nipple nodular lesion was confirmed as leiomyosarcoma will be presented, and as well its diagnosis and treatment in previous literature will be discussed.

\footnotetext{
$\star$ Corresponding author
}

\section{CASE REPORT}

A 52 year-old female patient has been noted with a slowly growing lump over the left nipple area since three months ago. Breast ultrasound revealed a lobulated lesion $1.5 \mathrm{~cm}$ in diameter in the 2 o'clock direction of the periareolar region. Excisional biopsy was performed. Grossly, the excised tumor was firm in consistency, and showed a white tan whorling cut surface, with an irregular tumor border. Microscopically, it shows a poorly circumscribed nodular mass composed of interlacing fascicles of spindle cells located in the dermis, separated from the overlying epidermis by a thin Grenz zone (Figs.1 and 2). The spindle cells exhibited cigar-shaped nuclei with blunt ends and eosinophilic cytoplasm. Moderate nuclear atypia was noted (Fig.3). The mitotic count was 7 mitoses per 10 high power fields (HPF) in the most 
active area. Necrosis and hemorrhage are absent. Immunohistochemically, the tumor cells were diffusely and strongly positive for $\alpha$-smooth muscle actin (Fig.4) and vimentin, while negative for cytokeratin, CD34 and S-100 protein.

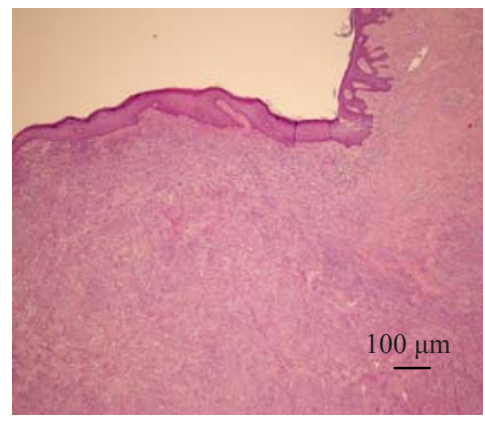

(a)

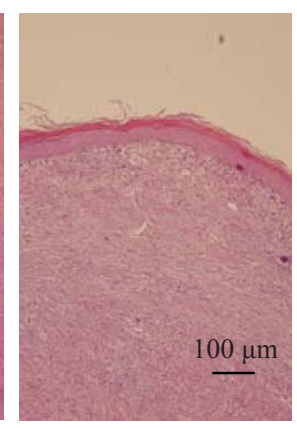

(b)
Fig.1 Under low magnification, a nodular tumorous lesion is noted in the dermis of the nipple-areola complex. (a) H \& E, ×40; (b) H \& E, $\times 100$

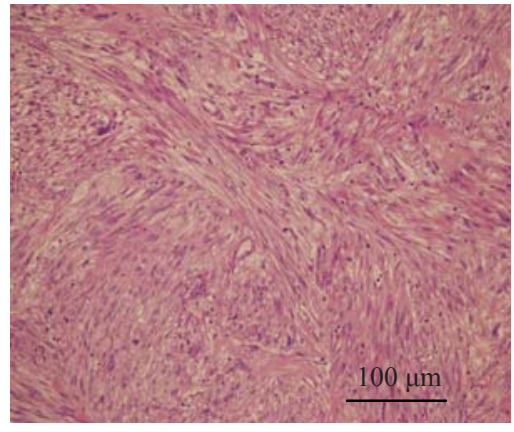

Fig.2 Intermediate magnification shows densely cellular tumor composed of interlacing fascicles of spindle cells $(\mathbf{H} \& \mathbf{E}, \times \mathbf{2 0 0})$

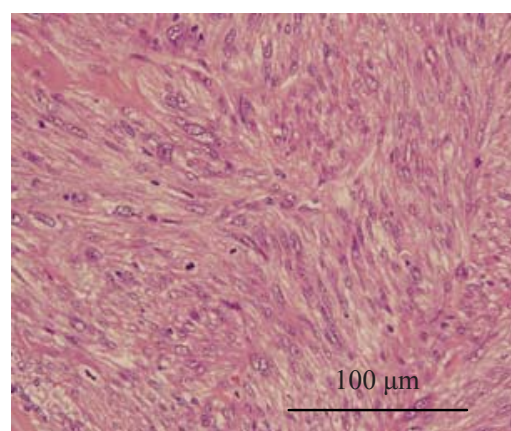

Fig.3 The tumor cells are characterized by cigar-shaped nuclei with blunt ends, moderate nuclear atypia, moderate amount of eosinophilic cytoplasm. Mitotic figure can be seen $(\mathrm{H} \& \mathrm{E}, \times 400)$

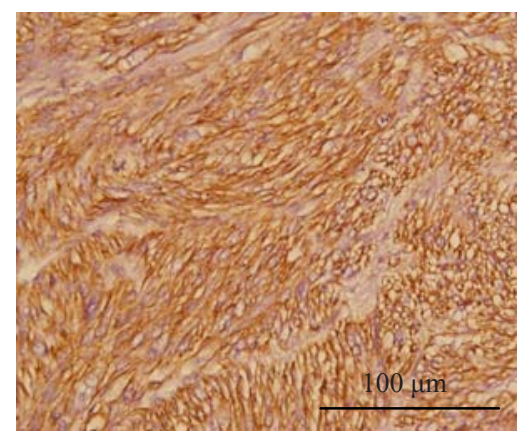

Fig.4 The immunohistochemical stains for $\alpha$-smooth muscle actin are diffusely and strongly positive in the tumor cells $(H \& E, \times 400)$

She was admitted to our ward for further evaluation and treatment. A series of surveys including whole body positron-emitted tomography (PET) revealed no other malignant lesions. Therefore, she underwent left simple mastectomy without axillary lymph node dissection. The pathological report revealed no residual tumor in the resected specimen. The post-operative course was uneventful and she was discharged $4 \mathrm{~d}$ after operation and underwent regular follow-up at our clinic.

\section{DISCUSSION}

Leiomyosarcoma is not rare among soft tissue tumors. It can exist in any part of the body. However, its most common primary sites are the uterus, retroperitoneum, subcutaneous tissues and gastrointestinal tract (Cohen et al., 2007; Insabato et al., 2004; Szekely et al., 2001). Leiomyosarcomas of the breast are extremely rare, either primary (Abd El All, 2006; Adem et al., 2004; Gupta, 2007; Hussien et al., 2001; Jayaram et al., 2005; Munitiz et al., 2004; Vu et al., 2006) or metastatic from other sites (Lin et al., 2003; Taillibert et al., 2000). The smooth muscle component might be originated from the blood vessels and sarcomatous change is usually from leiomyoma or other spindle cell tumors (Szekely et al., 2001). Our presented case should be regarded as primary leiomyosarcoma of the breast since there was no other primary focus being found after a series of surveys including PET scan.

The nipple-areola complex is a circular area of skin that exhibits increased pigmentation and contains numerous sensory nerve endings. The tip of the nipple 
contains 15 to 20 orifices of lactiferous ducts which are surrounded by a stroma rich in circular and longitudinal smooth muscle bundles, collagen and elastic fibers. The periphery of the nipple-areola complex also contains pilosebaceous units and hair. Therefore, the initial pathologic differential diagnoses should include tumors of both mammary and cutaneous origins. The differential diagnoses and their histological and immunohistochemical features are listed in Table 1.

The strong and diffuse cytoplasmic expression of $\alpha$-smooth muscle actin in this case, in additional to the typical cellular morphology, indicates smooth muscle origin of this tumor. According to the previously published cases of mammary, cutaneous and nipple-areola tumors, Ragsdale (1997)'s minimal criteria for cutaneous leiomyosarcomas, and the WHO classification of breast tumors (Tavassoli and Devilee, 2003), the presence of mitosis, nuclear atypia of various degree depending on differentiation, and hypercellularity are the most important criteria to designate a smooth muscle tumor as sarcoma. Tumor necrosis is not required for the diagnosis of malignancy.

Primary leiomyosarcoma of nipple-areola complex is rare. Table 2 illustrates the cases reported in English literature (Lonsdale and Widdison, 1992; Markaki et al., 2003; Uğraş et al., 1997). Histologically, the nipple-areola complex is cutaneous tissue composed of epidermis and dermis. However, in contrast to skin of other sites, it also contains lactiferous ducts that connect to the mammary parenchyma. Table 3 summarizes the clinical features, the treatment and outcome of primary leiomyosarcoma at the nipple-areola complex, the skin of other sites and the mammary parenchyma that reported in literature (Choy et al., 2006; Holst et al., 2002; Lonsdale and Widdison, 1992; Markaki et al., 2003; Uğraş et al., 1997). Tumors of these various sites had similar cytological and architectural characteristics. However,

Table 1 The initial differential diagnoses and their histological and immunohistochemical features

\begin{tabular}{|c|c|c|}
\hline Diagnoses & Histological features & Immunohistochemical features \\
\hline Leiomyoma & $\begin{array}{l}\text { Interlacing bundles of bland spindle cells with eosino- } \\
\text { philic cytoplasm and blunt-ended, cigar-shaped, ve- } \\
\text { sicular nuclei. Necrosis and mitosis are absent }\end{array}$ & $\begin{array}{l}\text { Diffusely and strongly positive for } \\
\alpha \text {-smooth muscle actin }\end{array}$ \\
\hline $\begin{array}{l}\text { Dermatofibrosarcoma } \\
\text { protuberans }\end{array}$ & $\begin{array}{l}\text { Fairly uniform spindle cells with elongated nuclei } \\
\text { showing little pleomorphism and pale cytoplasm, ar- } \\
\text { ranged in storiform or "rush mat" pattern }\end{array}$ & $\begin{array}{l}\text { Usually diffusely positive for } \\
\text { CD34, negative for S-100, } \\
\text { desmin and } \alpha \text {-smooth muscle } \\
\text { actin }\end{array}$ \\
\hline Leiomyosarcoma & $\begin{array}{l}\text { Infiltrative tumor composed of interlacing bundles of } \\
\text { cells with eosinophilic cytoplasm and blunt-ended, } \\
\text { cigar-shaped, often vesicular nuclei. Varied cyto- } \\
\text { logical pleomorphism }\end{array}$ & $\begin{array}{l}\text { Diffusely positive for } \alpha \text {-smooth } \\
\text { muscle actin, desmin and } h- \\
\text { caldesmon, negative for S-100 } \\
\text { and CD34 }\end{array}$ \\
\hline $\begin{array}{l}\text { Malignant peripheral } \\
\text { nerve sheath tumors }\end{array}$ & $\begin{array}{l}\text { Alternating myxoid and cellular areas containing ir- } \\
\text { regular interlacing bundles of spindle cells with } \\
\text { scanty pale cytoplasm and wavy, hyperchromatic, } \\
\text { variably pleomorphic nuclei. Myxoid change, hyaline } \\
\text { nodule and perivascular whorling may be present }\end{array}$ & $\begin{array}{l}50 \% \text { of these tumors are } S-100 \\
\text { positive, negative for } \alpha \text {-smooth } \\
\text { muscle actin }\end{array}$ \\
\hline $\begin{array}{l}\text { Malignant phyllodes tu- } \\
\text { mor }\end{array}$ & $\begin{array}{l}\text { Epithelial slits and hypercellular stroma showing } \\
\text { marked overgrowth of spindle cells. Prominent nu- } \\
\text { clear pleomorphism, mitotic count over } 10 \text { per } 10 \\
\text { HPF and infiltrative tumor border }\end{array}$ & $\begin{array}{l}\text { Spindle cells are positive for } \\
\text { vimentin and negative or only } \\
\text { focally positive for } \alpha \text {-smooth } \\
\text { muscle actin. Positive staining } \\
\text { for CD117 was reported }\end{array}$ \\
\hline $\begin{array}{l}\text { Malignant fibrous histio- } \\
\text { cytoma }\end{array}$ & $\begin{array}{l}\text { Prominently pleomorphic cells arranged in storiform } \\
\text { pattern. Bizarre multinucleated giant cells, and a } \\
\text { mononuclear inflammatory cell infiltrate with foamy } \\
\text { macrophages are often present. Most represent ex- } \\
\text { tension from deep soft tissue }\end{array}$ & $\begin{array}{l}\text { Negative for } \alpha \text {-smooth muscle } \\
\text { actin }\end{array}$ \\
\hline Sarcomatoid carcinoma & $\begin{array}{l}\text { A tumor composed of markedly atypical spindle and } \\
\text { pleomorphic epithelial cells, necrosis, and numerous } \\
\text { atypical mitotic figures }\end{array}$ & $\begin{array}{l}\text { Pleomorphic spindle cells are } \\
\text { positive for cytokeratin, nega- } \\
\text { tive for } \alpha \text {-smooth muscle actin }\end{array}$ \\
\hline $\begin{array}{l}\text { Spindle cell malignant } \\
\text { melanoma }\end{array}$ & $\begin{array}{l}\text { Groups of spindle cells exhibiting variable pigmentation } \\
\text { and pleomorphism }\end{array}$ & $\begin{array}{l}\text { Stain positively for S-100 protein } \\
\text { and HMB45, negative for } \\
\alpha \text {-smooth muscle actin }\end{array}$ \\
\hline
\end{tabular}


Table 2 Review of cases of primary leiomyosarcomas of the nipple-areola region

\begin{tabular}{|c|c|c|c|c|c|c|}
\hline Reference $^{*}$ & Site & Age/sex & Size $(\mathrm{cm})$ & Mitoses & Treatment & Follow-up \\
\hline $\begin{array}{l}\text { Crocker and } \\
\text { Murad, } 1969\end{array}$ & $\begin{array}{l}\text { Right, above } \\
\text { the nipple }\end{array}$ & $51 / \mathrm{male}$ & 5 & Common & Radical mastectomy & - \\
\hline $\begin{array}{l}\text { Pardo-Mindan } \\
\text { et al., } 1974\end{array}$ & $\begin{array}{l}\text { Left, near the } \\
\text { nipple }\end{array}$ & 49/female & 7 & 16/10 HPF & Simple mastectomy & Alive at 6 months, NET \\
\hline $\begin{array}{l}\text { Hemandez, } \\
1978\end{array}$ & $\begin{array}{l}\text { Left, involv- } \\
\text { ing nipple }\end{array}$ & $53 /$ male & 4 & 15/10 HPF & $\begin{array}{l}\text { Modified radical } \\
\text { mastectomy }\end{array}$ & $\begin{array}{l}\text { Alive at } 1 \text { year and } 2 \\
\text { months, NET }\end{array}$ \\
\hline $\begin{array}{l}\text { Yatsuka et al., } \\
1984\end{array}$ & $\begin{array}{l}\text { Left, beneath } \\
\text { the nipple }\end{array}$ & 56/female & 1.5 & 21/10 HPF & Radical mastectomy & $\begin{array}{l}\text { Alive at } 4 \text { years and } 7 \\
\text { months, NET }\end{array}$ \\
\hline Nielsen, 1984 & $\begin{array}{l}\text { Right, edge of } \\
\text { the areola }\end{array}$ & 24/female & $\begin{array}{l}1.5(1962) r \\
1(1965) r \\
2(1966) r\end{array}$ & $\begin{array}{l}2 / 10 \mathrm{HPF} \\
8 / 10 \mathrm{HPF} \\
14 / 10 \mathrm{HPF}\end{array}$ & $\begin{array}{l}\text { Excision in } 1960,1962 \\
\text { Excision } \\
\text { Excision and simple } \\
\quad \text { mastectomy }\end{array}$ & $\begin{array}{l}\text { Died } 20 \text { years later } \\
\text { with metastases to } \\
\text { brain, skin, thyroid } \\
\text { gland, and kidneys }\end{array}$ \\
\hline $\begin{array}{l}\text { Lonsdale et al., } \\
\quad 1992\end{array}$ & Left, areola & $60 /$ female & $\begin{array}{l}2 \\
4.5(18 \text { mon- } \\
\text { ths later }) \mathrm{r}\end{array}$ & 10/10 HPF & $\begin{array}{l}\text { Excision with } 1 \mathrm{~cm} \text { safe } \\
\text { margin } \\
\text { Excision with subsequent } \\
\text { mastectomy }\end{array}$ & $\begin{array}{l}\text { Alive at } 3 \text { months, } \\
\text { post-mastectomy, } \\
\text { NET }\end{array}$ \\
\hline $\begin{array}{l}\text { Uğraş et al., } \\
1995\end{array}$ & $\begin{array}{l}\text { Right, under } \\
\text { areola }\end{array}$ & 47/female & 2 & 3/10 HPF & $\begin{array}{l}\text { Total excision and sub- } \\
\text { cutaneous simple } \\
\text { mastectomy }\end{array}$ & $\begin{array}{c}\text { Alive at } 1 \text { year and } 6 \\
\text { months, NET }\end{array}$ \\
\hline $\begin{array}{l}\text { The present case } \\
\text { described in } \\
\text { this article }\end{array}$ & $\begin{array}{l}\text { Left, involv- } \\
\text { ing nip- } \\
\text { ple-areola } \\
\text { complex }\end{array}$ & $52 /$ female & 1.5 & 7/10 HPF & $\begin{array}{l}\text { Excision (July, 2007) and } \\
\text { subsequent total mas- } \\
\text { tectomy and regional } \\
\text { lymph node dissection }\end{array}$ & Alive \\
\hline
\end{tabular}

"All the references are from Uğraş et al.(1997); NET: No evidence of tumor; r: Recurrence

Table 3 Summary of the clinical features of primary leiomyosarcoma of various sites reported in literature

\begin{tabular}{|c|c|c|c|}
\hline & Clinical presentation & Treatment & Outcome \\
\hline $\begin{array}{l}\text { Leiomyosarcoma } \\
\text { of nipple-areola } \\
\text { complex }\end{array}$ & $\begin{array}{l}\text { More common in female. Solitary slow-growing } \\
\text { nodular lesion. May be asymptomatic. Possible ori- } \\
\text { gins: smooth muscle bundles surrounding lactiferous } \\
\text { ducts, arrector pili muscle at periphery of areola }\end{array}$ & $\begin{array}{l}\text { Excision, simple, } \\
\text { modified radi- } \\
\text { cal or radical } \\
\text { mastectomy }\end{array}$ & $\begin{array}{l}2 \text { of the } 7 \text { tumors listed } \\
\text { above recurred, } 1 \\
\text { metastasized }\end{array}$ \\
\hline $\begin{array}{l}\text { Leiomyosarcoma } \\
\text { of skin other than } \\
\text { nipple-areola } \\
\text { complex }\end{array}$ & $\begin{array}{l}\text { More common in men. Peak incidence: the sixth dec- } \\
\text { ade. Usually presents as a solitary nodule or plaque } \\
\text { on the extensor surfaces of extremities and less } \\
\text { commonly on the scalp and trunk. May be painful or } \\
\text { asymptomatic. Grow insidiously. Possible origins: } \\
\text { arrector pili muscle in the dermis or genital dartos } \\
\text { muscle }\end{array}$ & $\begin{array}{l}\text { Wide local exci- } \\
\text { sion with a } 3- \\
\text { to } 5 \text {-cm safe } \\
\text { margin }\end{array}$ & $\begin{array}{l}\text { Local recurrence rates: } \\
30 \% \sim 50 \% \text {, rarely } \\
\text { metastasize }\end{array}$ \\
\hline $\begin{array}{l}\text { Leiomyosarcoma } \\
\text { of mammary } \\
\text { parenchyma }\end{array}$ & $\begin{array}{l}\text { More common in female. Average age: } 52 \text { years. } \\
\text { Slow-growing solitary well-defined nodule. May be } \\
\text { asymptomatic. Possible origins: myoepithelium, } \\
\text { blood vessels }\end{array}$ & $\begin{array}{l}\text { Simple mastec- } \\
\text { tomy was rec- } \\
\text { ommended by } \\
\text { Uğraş et } \\
\text { al.(1997) }\end{array}$ & $\begin{array}{l}\text { Reported to have quite } \\
\text { high possibility of } \\
\text { recurrences or metas- } \\
\text { tases that occur he- } \\
\text { matogenously } \\
\text { (Markakietal, 2003) }\end{array}$ \\
\hline
\end{tabular}

for primary cutaneous leiomyosarcoma, treatment recommendations include a wide local excision with a 3- to 5-cm margin, including subcutaneous tissue and fascia; while mastectomy, including simple and modified radical mastectomy, is the most common treatment for breast leiomyosarcoma. Due to few cases of primary leiomyosarcoma of nipple-areola complex reported in literature so far, there is no general agreement on whether to treat them as cutaneous or mammary tumors, and the need of adjuvant radio-chemotherapy. An analysis of more cases with a longer follow-up duration is necessary to develop an optimum mode of treatment for leiomyosarcomas at this specific site.

\section{References}

Abd El All, H.S., 2006. Breast spindle cell tumours: About eight cases. Diagn. Pathol., 1(1):13. [doi:10.1186/17461596-1-13]

Adem, C., Reynolds, C., Ingle, J.N., Nascimento, A.G., 2004. Primary breast sarcoma: Clinicopathologic series from 
the Mayo clinic and review of the literature. Br. J. Cancer, 91:237-241.

Choy, C., Cooper, A., Kossard, S., 2006. Primary cutaneous diffuse leiomyosarcoma with desmoplasia. Aust. J. Dermatol., 47(4):291-295. [doi:10.1111/j.1440-0960.2006. 00298.x]

Cohen, D.T., Oliva, E., Hahn, P.F., Fuller, A.F.Jr, Lee, S.I., 2007. Uterine smooth-muscle tumors with unusual growth patterns: Imaging with pathologic correlation. AJR Am. J. Roentgenol., 188(1):246-255. [doi:10.2214/ AJR.05.1070]

Gupta, R.K., 2007. Needle aspiration cytology and immunohistologic findings in a case of leiomyosarcoma of the breast. Diagn. Cytopathol., 35(4):254-256. [doi:10. 1002/dc.20618]

Holst, V.A., Junkins-Hopkins, J.M., Elenitsas, R., 2002. Cutaneous smooth muscleneoplasms: Clinical features, histologic findings, and treatment options. J. Am. Acad. Dermatol., 46(4):477-490. [doi:10.1067/mjd.2002.121358]

Hussien, M., Sivananthan, S., Anderson, N., Shiels, A., Tracey, N., Odling-Smee, G.W., 2001. Primary leiomyosarcoma of the breast: Diagnosis, management and outcome. A report of a new case and review of literature. Breast, 10(6):530-534. [doi:10.1054/brst.2000.0276]

Insabato, L., Di Vizio, D., Ciancia, G., Pettinato, G., Tornillo, L., Terracciano, L., 2004. Malignant gastrointestinal leiomyosarcoma and gastrointestinal stromal tumor with prominent osteoclast-like giant cells. Arch. Pathol. Lab. Med., 128:440-443.

Jayaram, G., Jayalakshmi, P., Yip, C.H., 2005. Leiomyosarcoma of the breast: Report of a case with fine needle aspiration cytologic, histologic and immunohistochemical features. Acta Cytol., 49:656-660.

Lin, C.H., Yeh, C.N., Chen, M.F., 2003. Breast metastasis from uterine leiomyosarcoma: A case report. Arch. Gynecol. Obstet., 267:233-235.

Lonsdale, R.N., Widdison, A., 1992. Leiomyosarcoma of the nipple. Histopathology, 20(6):537-539. [doi:10.1111/ j.1365-2559.1992.tb01042.x]

Markaki, S., Sotiropoulou, M., Hanioti, C., Lazaris, D., 2003. Leiomyosarcoma of the breast. A clinicopathologic and immunohistochemical study. European Journal of $\mathrm{Ob}$ stetrics and Gynecology and Reproductive Biology, 106(2):233-236. [doi:10.1016/S0301-2115(02)00226-9]

Munitiz, V., Rios, A., Canovas, J., Ferri, B., Sola, J., Canovas, P., Illana, J., Parrilla, P., 2004. Primitive leiomyosarcoma of the breast: Case report and review of the literature. Breast, 13(1):72-76. [doi:10.1016/j.breast.2003.09.004]

Ragsdale, B.D., 1997. Lever's Histopathology of the Skin, 8th Ed. Lippincott-Raven, Chapter 35, p.959-960.

Szekely, E., Madaras, L., Kulka, J., Jaray, B., Nagy, L., 2001. Leiomyosarcoma of the female breast. Pathol. Oncol. Res., 7:151-153.

Taillibert, S., Spano, J.P., Genestie, C., Khayat, D., 2000. A mesocolic leiomyosarcoma metastatic to the breast: Case report and review of the literature. Anticancer Res., 20:4867-4869.

Tavassoli, F.A., Devilee, P., 2003. World Health Organization Classification of Tumours. Pathology and Genetics. Tumours of the Breast and Female Genital Organs. IARCPress, Lyon, p.98.

Uğraş, S., Dilek, O.N., Karaayvaz, M., Dilek, H., Peker, Ö., Barut, I., 1997. Primary leiomyosarcoma of the breast. Jpn. J. Surg., 27:1082-1085.

Vu, L.T., Luce, J., Knudson, M.M., 2006. Image of the month-leiomyosarcoma of the breast. Arch. Surg., 141(12):1263-1264. [doi:10.1001/archsurg.141.12.1263] 